\title{
PERAN OTORITAS JASA KEUANGAN DALAM PENGATURAN DAN PENGAWASAN JASA LAYANAN KEUANGAN BERBASIS TEKNOLOGI (FINANCIAL TECHNOLOGY)
}

\author{
Femmy Silaswaty Faried, Nourma Dewi; Universitas Islam Batik Surakarta, Jalan K. H. Agus \\ Salim Nomor 10 Surakarta; E-mail: femmysilaswaty@gmail.com
}

\begin{abstract}
Abstrak
Jasa layanan keuangan berbasis teknologi atau yang dikenal dengan financial technology atau yang disingkat dengan fintech adalah sebuah inovasi dalam bidang jasa keuangan. Fintech sangat diminati dan marak dipergunakan karena memberikan suatu produk dan layanan keuangan secara efisien. Meskipun adanya fintech bukan merupakan suatu cara untuk menggeser penggunaan pelaksanaan keuangan secara manual, karena fintech memiliki suatu tujuan untuk mempermudah bagi pengguna untuk menerima produk atau dana pinjaman. Berkaitan dengan hal tersebut adalah dibutuhkan suatu pengaturan yang jelas terhadap pendirian perusahaanperusahaan fintech itu sendiri dan hal tersebut telah diatur didalam Undang Undang Otoritas Jasa Keuangan secara rinci. Hal tersebut diperlukan untuk memberikan perlindungan hukum bagi pengguna fintech dan pelaku ekonomi itu sendiri. Tujuan penelitian ini adalah menelaah tugas fungsi tujuan serta kewenangan yang dimiliki oleh lembaga Otoritas Jasa keuangan. Metode penelitian yang dipergunakan dengan jenis penelitian normatif dengan sumber data sekunder dan bahan hukum primer, sekunder dan tersier yakni dengan cara mengkaji Peraturan PerundangUndangan yang berkaitan dengan Undang Undang Otoritas Jasa Keuangan. Pendapat para ahli hukum serta artikel-artikel ilmiah yang berkaitan dengan analisis data dan teknik pengumpulan data secara deskritif dengan memilah peraturan yang terkait. Pengaturan dan pengawasan fintech wajib dilakukan sesuai dengan peraturan dan ketentuan yang tentunya untuk melakukan antisipasi terhadap adanya fintech yang ternyata tidak memberikan perlindungan hukum bagi penggunanya maka didalam aturan fintech tersebut diatur secara jelas begitupun halnya dengan pembentukan Inovasi Keuangan Digital yang mengajukan diri sebagai pengawas dibawah atap lembaga Otoritas Jasa Keuangan seperti yang diatur didalam Undang Undang Otoritas Jasa Keuangan. Diperlukan sosialisasi terhadap peraturan terkait fintech bagi penggunanya.
\end{abstract}

Kata Kunci: Financial technology; Inovasi keuangan digital; Pelaku ekonomi.

\section{Abstract}

Technology-based financial services or known as financial technology or abbreviated to fintech is an innovation in the field of financial services. Fintech is in demand and is marginally used for providing a product and financial services efficiently. Although fintech is not a way to manually shift the use of financial implementation, because fintech has an objective to make it easier for users to receive products or loan funds. In relation to this it is necessary a clear arrangement of the establishment of the fintech companies themselves and it is regulated in the Financial Services Authority law in detail. It is necessary to provide legal protection for the users of fintech and economic actors themselves. The purpose of this research is to study the task of functions and the authority owned by the Financial Services Authority. The research method used with the type of normative research with secondary data source and primary, secondary and tertiary legal material is by reviewing the legislation relating to the Financial Services Authority Act. Opinions of legal experts and scientific articles relating to data analysis and data collection techniques in a deskritif by sorting through the relevant regulations. The arrangement and supervision of fintech must be done in accordance with the rules and provisions of course to anticipate the existence of a fintech that does not provide legal protection for its users, so in the rules of fintech is clearly regulated as well as the establishment of digital financial innovation which volunteered as a supervisor under the roof of the Financial Services Authority institution as stipulated in the Financial Services Authority Act. It is necessary to socialize with fintech regulations for users.

Keywords: Financial technology; Digital financial innovation; Economic actors. 


\section{PENDAHULUAN}

\section{Latar Belakang}

Pertumbuhan ekonomi dan perkembangan industri saat ini baik secara langsung maupun tidak langsung sangat memberikan kontribusi yang cukup signifikan terhadap tingkat kesejahteraan hidup masyarakat. Meningkatnya kesejahteraan hidup masyarakat di iringi dengan adanya kebutuhan akan layanan keuangan. Tentu saja, layanan keuangan selama ini pada umumnya diberikan oleh industri perbankan, di sisi lain meningkatnya kebutuhan layanan keuangan ternyata tidak di iringi dengan adanya pertumbuhan layanan keuangan oleh dunia perbankan. Hal ini menyebabkan adanya inaksesibilitas terhadap layanan keuangan. Sebagian masyarakat tidak memiliki akses yang memadai untuk menjangkau layanan keuangan yang dapat memenuhi kebutuhannya. Bahkan, sebagian lagi masyarakat sama sekali tidak dapat mengakses layanan keuangan yang diberikan oleh dunia perbankan. Kekurangan akses tentu saja adalah bagian penghambat bagi kencangnya laju pertumbuhan ekonomi dan juga untuk kesejahteraan masyarakat. Kekurangan dan keterbatasan akses tersebut justru merupakan suatu peluang bagi tumbuh kembangnya bisnis dan usaha industri layanan jasa keuangan non bank. Beberapa pihak selanjutnya respon terhadap kesempatan dan peluang yang ada dengan pemberian layanan jasa keuangan yang dapat terjangkau oleh sebagian masyarakat yang sebelumnya memiliki keterbatasan atau ketiadaan akses terhadap layanan jasa keuangan. Dalam memberikan layanan jasa keuangan ini, pihak pemberi layanan memanfaatkan dengan semaksimal mungkin teknologi komunikasi yang ada sehingga membuat layanan jasa keuangan ini dengan mudah aksesibilitasnya sehingga mampu dan mudah dijangkau oleh sebagian besar masyarakat.

Industri layanan keuangan pada dasarnya merupakan suatu cakupan pelayanan yang perlu diatur dan diawasi sehingga mampu menjamin tercukupinya hak dan kewajiban para pihak yang terkait didalam dunia layanan jasa keuangan. Telah diketahui bersama bahwa industri perbankan saat ini telah mendapatkan pengawasan yang sangat maksimal dari Otoritas Jasa Keuangan sehingga mampu tumbuh dan berkembang dengan baik serta tetap menjaga terpenuhinya hak-hak dan kewajiban para pihak yang ada didalamnya. Pengawasan ini tentunya juga harus dilakukan terhadap dunia layanan keuangan non bank termasuk didalamnya adalah industri teknologi layanan jasa keuangan non bank. Otoritas Jasa Keuangan tentunya wajib memberikan pengawasan terhadap dunia layanan jasa keuangan non bank sebagaimana yang selama ini dilakukan terhadap hal serupa yang dilakukan didalam dunia perbankan.

Peran pengawasan yang diamanatkan dalam Undang Undang Otoritas Jasa Keuangan adalah untuk terwujudnya suatu kepastian hukum. Maraknya layanan jasa keuangan non bank yang termasuk didalamnya adalah financial technology yang memberikan kemudahan bagi masyarakat yang membutuhkan dana menimbulkan banyak persoalan yang tentu saja merugikan pihak konsumen. Keterdesakan dan kemudahan mengakses informasi tentang pelayanan dan pemberian jasa keuangan non bank mengakibatkan para konsumen tanpa berpikir panjang mau memperoleh danadana segar yang tidak memberikan persyaratan jaminan namun demikian hal ini yang 
selanjutnya akan menimbulkan konflik dan kerugian bagi konsumen pemakai jasa layanan jasa keuangan non bank.

Pengawasan terhadap lembaga sektor jasa keuangan sebagaimana yang diatur dan diamanatkan dalam Undang Undang Nomor 23 Tahun 1999 Tentang Bank Indonesia. Undang Undang ini ada sebagai wujud dari pelaksanaan orde reformasi, yang mana saat itu bangsa Indonesia mengalami krisis keuangan saat itu dikenal krirsis moneter yang memberikan dampak perekonomian bangsa dan negara terpuruk. Pemikiran untuk membentuk suatu lembaga baru yang akan menyatukan pengawasan diberbagai sektor jasa keuangan sesuai yang diatur di dalam Undang Undang Nomor 23 Tahun 1999 Tentang Bank Indonesia.

Perihal adanya pemikiran tentang inisiatif pengaturan penyatuan tentang pengawasan berlangsung cukup lama. terbitnya Undang Undang Nomor 21 Tahun 2011 Tentang Otoritas Jasa Keuangan melakukan pengawasan serta pengaturan perbankan, pasar modal juga industri keuangan. Hadirnya lembaga Otoritas Jasa Keuangan di harapkan mampu memperbaiki sistem perekonomian di Indonesia yang sempat terpuruk akibat adanya krisis moneter. Perbaikan sistem perekonomian di titik beratkan pada kewenangan yang dimiliki oleh Bank Indonesia sebagaimana yang termuat di dalam Undang Undang Nomor 23 Tahun 1999 tentang Bank Indonesia yang selanjutnya dirubah dengan Undang Undang Nomor 3 Tahun 2004 menjelaskan bahwa tugas Bank Indonesia adalah untuk mencapai dan memelihara kestabilan nilai rupiah ${ }^{1}$ selanjutnya rancangan Undang Undang tersebut kemudian disahkan serta diundangkan yang oleh Dewan Perwakilan Rakyat di dalam Undang Undang Nomor 21 Tahun 2011 tentang Otoritas Jasa Keuangan dalam Lembaran Negara Republik Indonesia pada tanggal 22 November 2011. Peningkatan perekonomian tentu saja adalah tujuan yang dicapai oleh karena itu maka regulasi dari lembaga Otoritas Jasa keuangan yang memiliki fungsi dalam penyelenggaraan, sistem pengaturan serta pengawasan yang berhubungan dengan seluruh kegiatan dalam sektor jasa keuangan. Penelitian ini dilaksanakan untuk mengetahui secara jelas bagaimana peran lembaga Otoritas Jasa keuangan dalam penyelenggaraan pengaturan serta pengawasan terhadap jasa layanan keuangan berbasis teknologi (Financial Technology).

\section{Metode Penelitian}

Jenis Penelitian, Penelitian ini dilakukan dengan mempergunakan penelitian normatif, dengan melihat bagaimana lembaga Otoritas Jasa Keuangan sebagai suatu lembaga independen yang memiliki fungsi untuk menyelenggarakan sistem pengaturan dan pengawasan yang terintegrasi terhadap keseluruhan kegiatan di dalam sektor keuangan dan tentunya sesuai dengan peraturan perundang-undangan yang memayungi pengaturan, pelaksana dan pengawasannya. Sifat Penelitian, penelitian ini bersifat deskriptif yaitu meneliti suatu gejala, dalam hal ini dengan melihat menggambarkan bagaimana keberadaan lembaga otoritas jasa keuangan.

1 Undang-Undang Nomor 3 Tahun 2004 tentang Perubahan atas Undang-Undang Republik Indonesia Nomor 23 Tahun 1999 (Lembaran Negara Republik Indonesia Tahun 2004 Nomor 7, Tambahan Lembaran Negara Republik Indonesia Nomor 4357). 
Dalam hal pengaturan nyasebagaimana yang diatur dalam peraturan perundangundangan yang memayungi kewenangan Otoritas Jasa Keuangan. Hal ini disebabkan karena dengan perkembangan teknologi di era globalisasi menjadikan masyarakat dan pelaku ekonomi melakukan usaha untuk memenuhi kebutuhannya dengan cara yang mudah. Sumber Data, penelitian normatif mempergunakan sumber data sekunder sebagai sumber utamanya, yang terdiri tiga (3) bahan hukum, yaitu:

1) Bahan hukum primer, yaitu peraturan perundang-undangan, yakni Undang Undang Otoritas Jasa Keuangan;

2) Bahan hukum sekunder, yaitu pendapat dari para pakar hukum yang berkaitan dengan lembaga jasa keuangan perbankan dan non bank;

3) Bahan hukum tersier, yaitu yang berasal dari Kamus Besar Bahasa Indonesia dan kamus hukum serta artikel-artikel ilmiah yang berkaitan dengan penulisan fintech.

Metode Pengumpulan Data, dengan inventarisasi dan identifikasi data berupa peraturan perundang-undangan yang terkait. Teknik Analisis Data, pada penelitian ini pengolahan data dengan cara analisis data dilakukan dengan mensistematika terhadap bahan-bahan hukum tertulis yang ada, sistematika yang berarti membuat klasifikasi terhadap bahan-bahan hukum tersebut untuk memudahkan dan menyelesaikan penelitian ini. Metode Pendekatan yang dipergunakan adalah dengan menelaah asas asas hukum serta peraturan perundangan yang terkait, yakni undang-undang yang menjadi payung hukum pengaturan lembaga jasa keuangan, baik perbankan, non bank, baik secara konvensional maupun syariah dan baik secara langsung maupun melalui digital dengan beberapa jenis inovasi (financial technology).

\section{PEMBAHASAN}

Pengguna atau konsumen dari produk dan layanan jasa keuangan serta masyarakat luas diharapkan tidak hanya memahami produk dan jasa keuangan namun diperlukan juga perubahan sikap dan perilaku keuangan untuk mencapai kesejahteraan secara finansial. Pengetahuan dalam hal ini sangat dibutuhkan jasa keuangan yang ada. Otoritas Jasa Keuangan dalam peraturannya pada tahun 2016, menetapkan bahwa keuangan inklusif adalah ketersediaan akses pada berbagai lembaga, produk dan Layanan Jasa Keuangan sesuai dengan kebutuhan dan kemampuan masyarakat dalam rangka meningkatkan kesejahteraan masyarakat.

Perkembangan kemajuan teknologi tentu saja berdampak pada adanya kebutuhan akan modal sebagai suatu cara untuk menopang berdiri serta bertahannya suatu kemajuan teknologi yang nantinya akan mampu mempengaruhi pertumbuhan dan perkembangan keuangan perekonomian di era ini. Teknologi yang berkembang saat ini di segala aspek, mampu mempengaruhi tingkat pendapatan dan perekonomian bangsa pada khususnya dan negara pada umumnya. Terlebih pada pengikatan pertumbuhan teknologi dibidang keuangan.

Kebutuhan akan internet dengan media komputer maupun dengan media digital dengan smart phone yang semakin marak baik didunia pada umumnya maupun di negara Indonesia pada khususnya, tentunya membuka peluang yang besar bagi para 
pengusaha finansial dalam membesarkan usahanya. Lembaga keuangan perbankan, mulai melakukan pencatatan data yang mudah diakses dengan komputer, sehingga berkembanglah sistem layanan keuangan dengan mepergunakan teknologi semakin cepat, pemberian permodalan, investasi dengan mempergunakan teknologi. Sistem yang praktis dan mudah diperoleh dengan melalui teknologi tersebut semakin menarik ketimbang dengan cara manual.

Penggunaan smart phone serta internet yang makin marak, menjadikan pertumbuhan kemajuan teknologi dalam bidang keuangan semakin meningkat. Hal ini lah yang kemudian menyebabkan layanan jasa keuangan dengan berbasis teknologi semakin pesat berkembang. Metode yang dipergunakan dengan financial technologi tidak hanya dikenal pada layanan jasa keuangan di bidamg perbankan saja tetapi juga jasa keuangan non bank.

Kondisi geografis Indonesia memerlukan infrastruktur serta prasarana transportasi yang sangat baik untuk mampu mendistribusikan produk barang dan jasa dalam segala bidang dipelosok nusantara. Infrastruktur yang terbatas mengakibatkan sarana transportasi yang minim untuk tercapainya suatu mobilisasi produksi dan sekaligus kegiatan transaksi menjadi terhambat sehingga membuat masyarakat enggan untuk menggunakan produk keuangan formal dan lebih menggunakan layanan keuangan dari lembaga keuangan tradisional seperti koperasi dan jasa rentenir serta peminjaman secara online yang perlindungan hukumnya belum semuanya teradopsi dalam suatu bentuk peraturan.

Berdasarkan amanat Undang Undang Dasar Negara Reublik Indonesia Tahun 1945 (UUD NRI 1945) pada pembukaan alinea ke empat menjelaskan tujuan negara yaitu memajukan kesejahteraan umum yang selanjutnya dijabarkan dalam Pasal 33 UUD NRI 1945 yang berisi bahwa dalam dalam rangka mewujudkan perekonomian nasional yang bertumbuh dan tetap juga berkelanjutan serta menciptakan suatu bentuk kesempatan kerja yang luas dan seimbang di sektor ekonomi keuangan yang mampu memberikan kesejahteraan yang adil bagi seluruh rakyat, yang selanjutnya tujuan pembangunan tersebut di lanjutkan dalam pengaturan dengan berdirinya lembaga Otoritas Jasa Keuangan sebagai suatu lembaga independent memiliki tujuan, fungsi dan wewenangnan. Lembaga Otoritas Jasa Keuangan sangt berpengaruh baik secara eksternal maupun internal dalam persoalan ekonomi keuangan, baik bagi para lembaga jasa keuangan maupun orang pribadi maupun organisasi penggunanya.

Merujuk pada Pasal 4, Pasal 5, Pasal 6, Pasal 7, Pasal 8 dan Pasal 9 Undang-Undang Republik Indonesia Nomor 21 Tahun 2011 tentang Otoritas Jasa Keuangan (UU OJK) mengatur tentang tujuan, fungsi, tugas dan wewenang Otoritas Jasa Keuangan adalah sebagai berikut $:^{2}$

2 Undang-Undang Nomor 21 Tahun 2011 tentang Otoritas Jasa Keuangan (Lembaran Negara Republik Indonesia Tahun 2011 Nomor 111, Tambahan Lembaran Negara Republik Indonesia Nomor 5253), menurut peneliti adalah suatu pengaturan yang secara hierarkhi diatur lebih tegas dan peneliti berpendapat pengaturan tersebut jelas dan tegas mengatur pelaksanaan suatu proses layanan jasa keuangan. 


\section{Pasal 4}

Otoritas Jasa Keuangan dibentuk dengan tujuan agar keseluruhan kegiatan di dalam sektor jasa keuangan adalah :

a. terselenggara secara teratur, adil, transparan, dan akuntabel;

b. mampu mewujudkan sistem keuangan yang tumbuh secara berkelanjutan dan stabil; dan

c. mampu melindungi kepentingan konsumen dan masyarakat.

\section{Pasal 5}

Otoritas Jasa Keuangan berfungsi menyelenggarakan sistem pengaturan dan pengawasan yang terintegrasi terhadap keseluruhan kegiatan didalam sektor jasa keuangan.

\section{Pasal 6}

Otoritas Jasa Keuangan melaksanakan tugas pengaturan dan pengawasan terhadap :

a. kegiatan jasa keuangan di sektor Perbankan;

b. kegiatan jasa keuangan di sektor Pasar Modal; dan

c. kegiatan jasa keuangan di sektor Perasuransian, Dana Pensiun, Lembaga Pembiayaan dan Lembaga Jasa Keuangan Lainnya.

\section{Pasal 7}

Untuk melaksanakan tugas pengaturan dan pengawasan di sektor Perbankan sebagaimana dimaksud dalam Pasal 6 huruf a, Otoritas Jasa Keuangan mempunyai wewenang :

a. pengaturan dia pengawasan mengenai kelembagaan bank yang meliputi :

1. perizinan untuk pendirian bank, pembukaan kantor bank, anggaran dasar, rencana kerja, kepemilikan, kepengurusan dan sumber daya manusia, merger, konsolidasi dan akusisi bank, serta pencabutan izin usaha bank; dan

2. kegiatan usaha bank, antara lain sumber dana, penyediaan dana, produk hibridasi dan aktivitas di bidang jasa;

b. pengaturan dan pengawasan mengenai kesehatan bank yang meliputi :

1. likuiditas, rentabilitas, solvabilitas, kualitas asset, rasio kecupuan modal minimum, batas maksimum pemberian kredit, rasio pinjaman terhadap simpanan, dan pencadangan bank;

2. laporan bank yang terkait dengan kesehatan dan kinerja bank;

3. sistem informasi debitur;

4. pengujian kredit (credit testing); dan

5. standar akuntansi bank;

c. pengaturan dan pengawasan mengenai aspek kehati-hatian bank, meliputi :

1. manajemen risiko;

2. tata kelola bank;

3. prinsip mengenal nasabah dan anti pencucian uang; dan

4. pencegahan pembiayaan terorisme dan kejahatan perbankan; dan

d. pemeriksaan bank.

\section{Pasal 8}

Untuk melaksanakan tugas pengaturan sebagaimana dimaksud dalam Pasal 6, Otoritas Jasa Keuangan mempunyai wewenang :

a. menetapkan peraturan pelaksanaan Undang-Undang ini;

b. menetapkan peraturan perundang-undangan di sektor jasa keuangan;

c. menetapkan peraturan dan keputusan Otoritas Jasa Keuangan;

d. menetapkan peraturan mengenai pengawasan di sektor jasa keuangan; 
e. menetapkan kebijakan mengenai pelaksanaan tugas Otoritas Jasa Keuangan;

f. menetapkan peraturan mengenai tata cara penetapan perintah tertulis terhadap Lembaga Jasa Keuangan dan pihak tertentu;

g. menetapkan peraturan mengenai tata cara penetapan pengelola statute pada Lembaga Jasa Keuangan;

h. menetapkan struktur organisasi dan infrastruktur, serta mengelola, memelihara, dan menatausahakan kekayaan dan kewajiban; dan

i. menetapkan peraturan mengenai tata cara pengenaan sanksi sesuai dengan ketentuan peraturan perundang-undangan di sektor jasa keuangan.

\section{Pasal 9}

Untuk melaksanakan tugas pengawasan sebagaimana dimaksud dalam Pasal Pasal 6, Otoritas Jasa Keuangan mempunyai wewenang :

a. menetapkan kebijakan operasional pengawasan terhadap kegiatan jasa keuangan;

b. mengawasi pelaksanaan tugas pengawasan yang dilaksanakan oleh Kepala Eksekutif;

c. melakukan pengawasan, pemeriksaan, penyidikan, perlindungan Konsumen, dan tindakan lain terhadap Lembaga Jasa Keuangan, pelaku, dan/atau penunjang kegiatan jasa keuangan sebagaimana dimaksud dalam peraturan perundang-undangan disektor jasa keuangan;

d. memberikan perintah tertulis kepada Lembaga Jasa Keuangan dan/atau pihak tertentu;

e. menetapkan penunjukan pengelola statuter;

f. menetapkan penggunaan pengelola statuter;

g. menetapkan sanksi admnistratif terhadap pihak yang melakukan pelanggaran terhadap peraturan perundang-undangan di sektor jasa keuangan; dan

h. memberikan dan/atau mecabut;

1. izin usaha;

2. izin orang perseorangan;

3. efektifnya pernyataan pendaftaran;

4. surat tanda terdaftar;

5. persetujuan melakukan kegiatan usaha;

6. pengesahan;

7. persetujuan atau penetapan pembubaran; dan

8. penetapan lain

Perihal pelaksanaan jasa layanan keuangan dengan berbasis pada Teknologi (financial technology) sebagaimana yang diatur dalam Pasal 6 huruf K UU OJK, jelas memberikan kewenangan kepada Otoritas Jasa Keuangan untuk melakukan pengaturan dan pengawasannya. Financial Tecnology adalah suatu cara/metode yang dipergunakan oleh lembaga jasa keuangan di sektor Perbankan, pasar modal, maupun lembaga non bank.

Financial Technology adalah suatu bentuk kemajuan teknologi yang luar biasa sehingga menimbulkan bentuk inovasi dari layanan jasa penyedia dana yang mudah untuk diakses Jenis-jenis financial technology di Indonesia adalah sebagai berikut : 3

1. Pertama, Payment, Clearing Dan Settlement. Fintech ini memberikan layanan sistem pembayaran yang diselenggarakan oleh industri perbankan maupun yang dilakukan Bank Indonesia seperti Bank Indonesia Real Time Gross Settlement (BI-RIGS)

3 Anonim. https://www.cnbcindonesia.com/tech/20180110145800-37-1126/ini-dia-empat-jenisfintech-di-indonesia, diakses pada tanggal 01 September 2019 pukul 23.00 WIB. 
2. Kedua, E-Aggregator. Fintech ini melakukan pengumpulan dan pengolahan data yang bisa dimanfaatkan konsumen untuk pengambilan keputusan (memberikan perbandingan produk mulai dari harga, fitur dan manfaat).

3. Ketiga, Manajemen Resiko dan Investasi ini memberikan pelayanan seperti robo advisor (perangkat lunak) yang memberikan layanan perencanaan keuangan dan platform $e$ trading.

4. Keempat, peer to peer (P2P). Fintech ini mempertemukan antara pemberi pinjaman (investor) dengan para pencari pinjaman dalam suatu platform yang nantinya para investor akan menerima bunga dari dana yang dipinjamkannya.

5. Kelima, suatu aktivitas keuangan yang diwadahi oleh Lembaga Jasa Keuangan yang tentunya berada dibawah pengawasan Otoritas Jasa Keuangan.

Maka dengan kata lain dapat disimpulkan bahwa financial technology memiliki tujuan memberikan kemudahan kepada masyrakat untuk mengakses produk keuangan, memudahkan transaksi serta peningkatan literasi keuangan.

Perubahan paradigma berpikir yang mana untuk mencari kemudahan mendapatkan dana adalah konsep sistem konvensional menjadi konsep digitalisasi. Hal ini lah yang menyebabkan Layanan Jasa Keuangan dengan model peminjaman online semakin diminati meskipun hal tersebut akan memberikan resiko bagi konsumennya. Peran pentingnya Otoritas Jasa Keuangan, lembaga yang dipercaya sebagai pengawas ini diharapkan mampu memberikan solusi baik penanggulangan maupun pencegahan terjadinya suatu hal yang akan berdampak buruk bagi masyarakat pengguna pada khususnya dan perekonomian Indonesia pada umumnya. Konsep sistem Layanan Jasa Keuangan dengan digitalisasi sangat diminati terutama bagi masyarakat yang tentunya tidak ingin banyak urusan dengan pemenuhan persyaratan sebagaimana ketika mengajukan dana pinjaman dengan cara manual, masyarakat Indonesia mudah tergiur karena kemudahan yang ada.

Inovasi keuangan digital semestinya diarahkan ke hal yang bermanfaat dan bertanggungjawab sehingga mampu memberikan pengamanan dan perlindungan terhadap konsumen yang memakainya sehingga terhindar dari resiko. Mekipun yang kerap terjadi dan perlu perhatian adalah adanya pemberian bunga yang sesuai dengan peraturan perundang-undangan yang ada. sehingga jikapun ada resiko dapat terkendali dengan baik. Dasar hukum dalam pengawasan dan pengaturan Industri financial disektor Jasa Keuangan adalah pada Pasal 1 ayat (1) Peraturan Otoritas Jasa Keuangan Nomor 13/POJK.02/2018 tentang Inovasi Keuangan Digital di sektor jasa keuangan adalah "suatu aktivitas pembaharuan dalam proses bisnis, model bisnis dan instrumen keuangan yang memberikan nilai tambah baru di sektor jasa keuangan dengan melibatkan ekosistem digital, selanjutnya menjelaskan bahwa fintech adalah suatu lembaga jasa keuangan yang merupakan inovasi dari keuangan digital, yang mengatur mekanisme pencatatan dan pendaftaran fintech.

Penyelenggara inovasi keuangan digital baik perusahaan start up maupun Lembaga Jasa Keuangan akan melalui 3 tahap proses sebelum mengajukan permohonan perizinan yaitu : 
a. Pencatatan kepada Otoritas Jasa Keuangan untuk perusahaan start up atau non lembaga jasa keuangan. Permohonan pencatatan secara otomatis termasuk permohonan pengujian regulatory sandbox. Sedangkan untuk lembaga jasa keuangan, permohonan sandbox diajukan kepada pengawas masing-masing bidang (perbankan, pasar modal, industri keuangan bukan bank)

b. Proses regulatory sandbox berjangka waktu paling lama satu tahun dan dapat diperpanjang selama 6 bulan bila diperlukan

c. Pendaftaran/perizinan kepada Otoritas Jasa Keuangan

Sedangkan mekanisme pemantauan dan pengawasan fintech menetapkan penyelenggara inovasi keuangan digital yang wajib mengikuti proses regulatory sandbox. penyelenggara inovasi keuangan digital yang sudah menjalani regulatory sandbox untuk pelaksanaan pemantauan dan pengawasan, penyelenggara inovasi keuangan digital diwajibkan untuk melakukan pengawasan secara mandiri dengan menyusun laporan self assessment yang sedikitnya memuat aspek tata kelola dan mitigasi risiko.

Penyelenggara Inovasi Keuangan Digital dilarang mencantumkan nama dan/atau logo Otoritas Jasa Keuangan namun dapat mencantumkan nomor tanda tercatat/terdaftar. Dalam jangka menengah, Otoritas Jasa Keuangan dapat menunjuk pihak lain (Asosiasi Penyelenggara Inovasi Keuangan Digital yang diakui oleh Otoritas Jasa Keuangan) yang bertugas dalam pengawasan Inovasi Keuangan Digital.

a. Pembentukan Ekosistem Fintech

b. Membangun Budaya Inovasi

c. Inklusi dan Literasi

Pada Pasal 2 Ayat (2) Peraturan Otoritas Jasa Keuangan No. 13/POJK.02/2018 tentang Inovasi Keuangan Digital di Sektor Jasa Keuangan di Sektor Jasa Keuangan dilakukan dengan tujuan untuk:

a. mendukung pengembangan IKD yang bertanggung jawab;

b. mendukung pemantauan IKD yang efektif; dan

c. mendorong sinergi di dalam ekosistem digital jasa keuangan.

Perihal persyaratan penyelenggaraan diatur dalam Pasal 8 Peraturan Otoritas Jasa Keuangan No. 13/POJK.02/2018 tentang Inovasi Keuangan Digital di Sektor Jasa Keuangan :

1) Otoritas Jasa Keuangan menetapkan Penyelenggara untuk diuji coba dalam Regulatory Sandbox.

2) Penetapan sebagaimana dimaksud pada ayat (1) dilakukan terhadap Penyelenggara yang memenuhi persyaratan paling sedikit :

a. tercatat sebagai inovasi keuangan digital di Otoritas Jasa Keuangan atau berdasarkan surat permohonan yang diajukan satuan kerja pengawas terkait di Otoritas Jasa Keuangan;

b. merupakan bisnis model yang baru;

c. memiliki skala usaha dengan cakupan pasar yang luas;

d. terdaftar di asosiasi penyelenggara; dan

e. kriteria lain yang ditetapkan oleh Otoritas Jasa Keuangan. 


\section{PENUTUP}

Pengaturan pelaksanaan dan pengelolaan lembaga jasa keuangan di Indonesia telah memiliki paung hukum yang jelas dengan dikeluarkanya peraturan perundangundangan terkait dan juga peraturan pelaksanaannya yang dikeluarkan oleh suatu lembaga yang kewenangannya diatur dalam undang-undang yakni lembaga Otoritas Jasa Keuangan

Diperlukan pengaturan teknis dalam hal pengawasan suku bunga yang diberikan, sehingga konsumen yang memanfaatkan jasa layanagn keuangan berbasis teknoogi tidak merasa dirugikan dan tetap hak nya terlindungi dengan baik.

\section{DAFTAR PUSTAKA}

\section{Buku :}

Achmad Ali. 1996. Menguak Tabir Hukum. Cetakan Pertama. Chandra Pratama, Jakarta. Jamal Wiwoho, 2011. Hukum Perbankan Di Indonesia. Cetakan Kesatu, Upt Penerbitan dan Percetakan UNS (UNS Press), Surakarta.

Kasmir, 2011. Manajemen Perbankan. Cetakan kedua, PT RajaGrafindo Persada, Jakarta.

Lukman Santoso AZ, 2011. Hak dan Kewajiban Hukum Nasabah Bank. Penerbit Pustaka Yustisia, Yogyakarta.

Morris I Kohen and Olson. C.Kent. 2000. Legal Research, ST. Paul. Minn.

Philipus M. Hadjon dan Tatiek Sri Djatmiati. 2008. Argumentasi Hukum. Cetakan Ketiga.Gadjah Mada University Press, Yogyakarta.

Pieter Mahmud Marzuki. 2010. Penelitian Hukum. Cetakan Keenam. Kencana Prenada Media Group, Jakarta.

Soerjono Soekanto dan Sri Mamudji. 2007. Penelitian Hukum Normatif, Suatu Tinjauan Singkat. PT. Raja Grafindo Persada, Jakarta.

Soerjono Soekanto. 1984. Penelitian Hukum. UI Press, Jakarta

Sutan Remy Sjahdeini, 1993. Kebebasan Berkontrak Dan Perlindungan Yang Seimbang Bagi Para Pihak Dalam Perjanjian Kredit Di Indonesia. Institut Bankir Indonesia, Jakarta.

\section{Peraturan Perundang-Undangan :}

Undang-Undang Dasar Negara Kesatuan Republik Indonesia Tahun 1945

Undang-Undang Nomor 3 Tahun 2004, Tentang Perubahan atas Undang-Undang Nomor

23 Tahun 1999, Tentang Bank Indonesia

Undang-Undang Nomor 21 Tahun 2011, Tentang Otoritas Jasa Keuangan

\section{Internet / Media Online :}

https://id.wikipedia.org/wiki/Otoritas_Jasa_Keuangan, diakses pada tanggal 01 September 2019 pukul 22.00 WIB.

https://www.maxmanroe.com/vid/finansial/lembaga-keuangan-bukan-bank.html, diakses pada tanggal 01 September 2019 pukul 22.00 WIB.

https:// www.coursehero.com/file/p50ve1c/Dasar-hukum-lembaga-keuangan-bukan-

bank-adalah-1-Surat-Keputusan-Menteri, diakses pada tanggal 01 September 2019 pukul 22.00 WIB. 
http:/ / www.digipedia.web.id/2016/11/perbedaan-lembaga-keuangan-bank-dannon.html, diakses pada tanggal 01 September 2019 pukul 23.00 WIB.

https:// www.maxmanroe.com/mengenal-fintech-inovasi-sistem-keuangan-di-eradigital.html, diakses pada tanggal 01 September 2019 pukul 23.00 WIB.

https:// www.hukumonline.com/berita/baca/lt5a97b394460ec/aspek-hukum-fintech-diindonesia-yang-wajib-diketahui-lawyer/, diakses pada tanggal 01 September 2019 pukul 23.00 WIB. 